\title{
AVIATION/AEROSPACE FORECAST 2005: INDUSTRY AND EMPLOYMENT OUTLOOK
}

\author{
Virginia Lee Lussier \\ Parks College of Saint Louis University
}

\begin{abstract}
This paper briefly examines the current economic status of the aviation/ aerospace industry, its projected growth to the year 2005, and the prospects for different aviation-related careers during the next decade. Since 1960, the industry has faced a series of boom and bust cycles. As a result of programs to severely cut airline costs, a healthy economy, and continued airline traffic growth, the financial picture for the industry in the decade ahead looks better than it has since 1989, although not all analysts agree on the scope and profitability of that growth. These industry changes, coupled with technological advances, will alter the industry and its workforce requirements. New scientific and management skills will be required. Finally, the paper examines the anticipated demand for personnel in various aviation/aerospace fields from 1995 to 2005.
\end{abstract}

\section{Introduction}

The highly diverse aviation and aerospace industry in the United States not only serves the traveling public and the world's defense establishments, but it has considerable impact on the U.S. economy as a source of employment. It is closely linked to the nation's economic cycle, and since 1960 labor demands have shifted cyclically between critical shortage and excess supply. Depending on the cycle of boom or bust, the industry employs between 750,000 and 1.3 million pilots, mechanics, engineers, computer scientists, reservation clerks, and other specialists (Oklahoma Regents, 1994). This paper examines briefly the current economic status of the aviation/aerospace industry, its projected growth to the year 2005, and the prospects for different aviation/aerospace related jobs during the next decade.

\section{Industry Trends}

Since 1960, the U.S. commercial airline industry has faced a series of boom and bust cycles. The boom years correspond to an expansionist economy and stable or declining oil prices while the bust cycles reflect a recessionist economy and high oil costs. Prior to 1994, the last year the industry reported a profit was 1989 when carriers reported a gain of $\$ 128$ million (Velocci, $1995)$. In the intervening years, the industry lost $\$ 3.0$ billion in $1990, \$ 1.9$ million in 1991, $\$ 4$ billion in 1992, and $\$ 2.1$ billion in 1993 (Velocci, 1995). All major passenger carriers except Southwest Airlines suffered losses, Eastern and Pan American were liquidated, and three additional major airlines filed for bankruptcy protection.

The picture changed in 1995. As a result of competitive pressure, every major airline launched a program to severely cut costs. These programs included restructuring operations, reducing excess capacity, withdrawal from unprofitable routes, retining inefficient aircraft, 
reducing food service, and shifting to ticket less reservations and booking, among other measures (Murphy, 1995). In addition, the three airlines under bankruptcy protection have emerged from Chapter 11 proceedings. Coupled with a healthy economy, the major airlines showed a profit of $\$ 2.4$ billion in 1994 (Murphy, 1995). In 1995, U.S. commercial airlines made $\$ 5.3$ billion dollars, the most profitable year ever (Hinson, 1996b). These trends are continuing in 1996.

Table I

Airline Industry: Boom/Bust Cycle

\begin{tabular}{|l|c|c|l|}
\hline Cycle & Years & Duration & \multicolumn{1}{|c|}{ Industry } \\
\hline Boom & $1960-68$ & 9 & Jet Age; Mass Travel \\
\hline Bust & $1969-74$ & 6 & Wide-body Ear; Excess Capacity \\
\hline Boom & $1975-79$ & 5 & Defacto Regulation \\
\hline Bust & $1980-82$ & 3 & Deregulation \\
\hline Boom & $1983-89$ & 7 & Mergers and Acquisitions \\
\hline Bust & $1990-94$ & 5 & $\begin{array}{l}\text { Overcapacity; Hypercompetitive } \\
\text { Environment; Growing Debt }\end{array}$ \\
\hline Boom & $1995-2000$ & 6 & $\begin{array}{l}\text { Opeating and Financial Restructing to } \\
\text { Reduce Costs and Improve Profits; } \\
\text { Higher Load Factors }\end{array}$ \\
\hline
\end{tabular}

Note. Adapted from Anthony L. Velocci, 1994, Aviation Week \& Space Technology, 142(110, p.45.

Simultaneously, the U.S. aerospace industry suffered a downturn in its defense market. Aerospace sales to the U.S. military fell almost $\$ 30$ billion since 1987 while those to foreign customers declined as well (Vadas, 1995). The dramatic decline in world arms deliveries has been precipitated primarily by the end of the Cold War, political and economic upheaval in Russia that ended foreign-aid-supported military exports, and limited national budgets in developing countries that restrict government military spending (Lopez, 1994). Between 1987 and $1993,60 \%$ of the defense-related jobs lost, 989,000 positions, were in the private sector. The remaining 40\% were in the Armed Forces and Pentagon (Saunders, 1995). By 1999, the Bureau of Labor Statistics projects that defense-related employment will have fallen an additional 1.3 million, to 4.3 million (Saunders, 1995). 
Table 2

Projected Defense-Related Employment by Selected Industry, 1993 and 1999 (thousands of jobs)

\begin{tabular}{|l|c|c|c|}
\hline Industry Employment & 1993 & 1999, Projected & $\begin{array}{c}\text { Projected Decline } \\
\text { 1993 to 1999 }\end{array}$ \\
\hline Total Defense- Related & $5,595.3$ & $4,289.8$ & $1,305.5$ \\
\hline Aircraft & 111.9 & 78.6 & 33.3 \\
\hline $\begin{array}{l}\text { Guided Missiles and } \\
\text { Space Vechicles }\end{array}$ & 76.3 & 53.7 & 22.6 \\
\hline Aircraft and Missile Parts & 82.4 & 64.4 & 18.0 \\
\hline $\begin{array}{l}\text { Aircraft and } \\
\text { Missile Engines }\end{array}$ & 64.6 & 47.5 & 17.1 \\
\hline $\begin{array}{l}\text { Search and Navigation } \\
\text { Equipment }\end{array}$ & 59.1 & 43.3 & 15.8 \\
\hline $\begin{array}{l}\text { Communications } \\
\text { Equipment }\end{array}$ & 42.2 & 1.1 & 41.1 \\
\hline $\begin{array}{l}\text { Miscellaneous Electronic } \\
\text { Components }\end{array}$ & 47.8 & 36.8 & 11.0 \\
\hline
\end{tabular}

Note. Adapted from Norman C. Saunders, 1995, Occupational Outlook Quarterly, 39 (2), p. 33.

\section{Industry Growth Prospects}

Major growth in the airline industry is expected in the commercial market, although not all analysts agree on the scope and profitability of that growth. The airline industry's financial prospects are dependent both on the overall growth of the economy and on continued airline traffic growth, itself a function of the economy. The U.S. Office of Management and Budget forecasts the growth of Gross Domestic Product at approximately $2.6 \%$ between 1995 and 2001 , and 2.4\% from 2002 to 2005 (Murphy, 1995). With these economic forecasts as a basis, the Federal Aviation Administration (FAA) projects that current strong airline traffic growth rates will continue for the next two years, and then continue at a healthy $4.2 \%$ through 2005 . The FAA foresees airline traffic of 537 billion route passenger miles in 1995, 567 billion in 1996, and 869 billion by 2006 (Murphy, 1995). In addition, the FAA is forecasting that the number of commuter passengers will increase from approximately 58 million in 1995 to 174 million over the next 12 years (Hinson, 1995a). As the number of passengers increase, the FAA estimates that the commercial aircraft fleet will expand from 6,605 in 1995 to 9,781 in 2006 (Murphy, 1995; BNA, 1995). Air cargo is projected to grow an average of $6.6 \%$ annually over the next decade (Hinson, 1996a). "To handle this heavy volume of passengers and cargo, airlines will have to double the size of the existing fleet, buying 15 to 17 thousand new planes by the end of 2016 ...Aircraft deliveries are expected to double by the year 2002 or 2003 , then double again within 20 years" (Hinson, 1996a, 1996d).

With cost reductions and continued strong growth in airline traffic, the airlines' operating profits will rise. The emerging consensus among industry analysts is that all components of the commercial airline industry are on the rise. For example, Aviation Information Resources, Inc. 
forecasts the world's aircraft fleet to grow from 9,800 aircraft in 1990 to over 15,700 by 2005 , a 61\% increase (Oklahoma Regents, 1994; Sparaco, 1994). They also project the U.S. jet fleet to increase from 4,720 in 1990 to 6,519 in the year 2005, a 38\% increase (Oklahoma Regents, 1994; Kandebo, 1995). Asia and the Pacific are forecast to be the fastest growing regions with 1,224 aircraft in 1990 expanding to 2,534 aircraft in 2005, a 108\% growth (Meecham, 1994). Europe, on the other hand, is expected to grow from 2,045 aircraft in 1990 to 3,977 by 2005 , a 94\% fleet growth (Shifrin, 1995). Almost every major U.S. carrier is now in the international market carrying approximately 50 million passengers a year. This represents an increase of $30 \%$ in the last five years (Hinson, 1995b).

Figure 1

The World's Aircraft Fleet

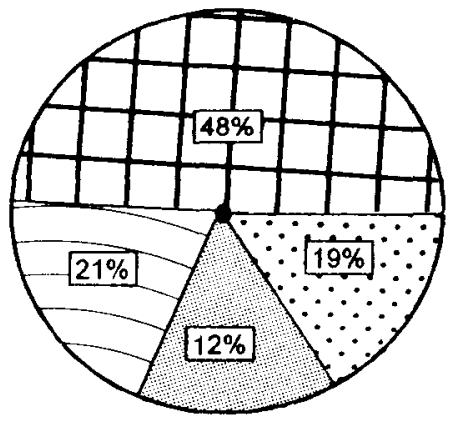

1990 World Total 9,800 Aircraft

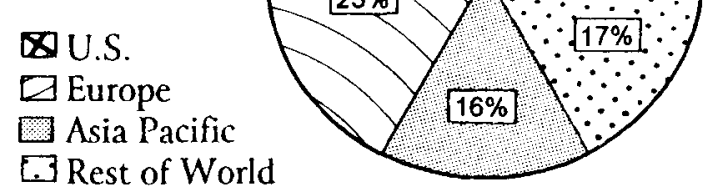

Projected 2005 World Total 15,700 Aircraft

\section{Technological Needs}

Coupled with the growth trends, are also technological trends that will alter the industry and the work force. These include such changes as: a) larger commercial aircraft size resulting in the need for airport redesign and new systems of ground transportation; b) faster travel at higher altitudes resulting in the need for new materials that are stronger and lighter; and c) on-board maintenance systems that will result in electronically displayed data rather than data displayed on paper (Oklahoma Regents, 1994). As technological advances continue, the aviation/ aerospace work force will, among other things, be required to possess skills in working with computer based equipment and information systems. Engineers and technicians will be needed who have skills in more than one discipline, are able to synthesize what they have learned, are creative and approach problems in different ways, use different methods to obtain solutions to a problem, and work together in cohesive team-oriented groups. They need practical hands-on activity that emphasizes engineering judgement and design capability.

Similarly, the work force will be required to work at a rapid pace in a world focused on low prices, reliability and rapid product changes. This type of work environment will require aviation/aerospace employees to understand and utilize management principles with a heavy emphasis placed on statistical process controls. Further, technological improvements will require the work force to have strong academic underpinnings in basic skills such as mathematics, science, and communication, in addition to having improvements in interdisciplinary knowledge and the applied sciences (Ladesic \& Hazen, 1995; Maul, 1994). 


\section{Employment Needs and Job Opportunities}

Total employment in the U.S. is expected to increase from 121.1 million in 1992 to 147.5 million in 2005, or by 22\% (BLS, 1994b; Gradler \& Schrammel, 1994). The Bureau of Labor Statistics (BLS) predicts that 26.4 million jobs will be added to the U.S. economy by 2005 . Those jobs will be created in three ways: growth, upgrading, and replacement needs (Shelley, 1994). These avenues are expected to create close to a million jobs annually for college graduates between 1995 and 2005 (Shelley, 1994; Gradler \& Schrammel, 1994). More than half the new and upgraded jobs will be in professional specialty occupations. These include positions such as engineers; computer systems analysts and programmers; operations research analysts; and in various communications occupations, among others. As a whole, this group is expected to continue to grow faster than average and to increase its share of total employment significantly by 2005 (Oberman \& Nagle, 1995). Rapid changes in technology, demographics, and ways of conducting business will cause some of these occupations to grow faster than others (BLS, 1994b).

What are the future employment needs and career opportunities in the diverse aviation/aerospace industry? The job prospects for the year 2005 in some of the areas are outlined briefly below:

\section{Airline Pilot}

Money magazine's 1995 job report ranks 50 skilled professions that are projected to grow fastest by the year 2005, one of those positions is that of airline pilot (Marable, 1995). Both the Federal Aviation Administration and the BLS predict major demands for new pilots in the next ten years. The FAA forecasts that a total of 157,500 airline pilots will be needed by 2005 (Field, 1995; Wilhilmsen, 1995). Between December 1993 and December 1994, the airlines hired about 8,300 new pilots, an increase of $45 \%$. If the recent trend of increased hiring continues at the same time that the number of new student pilots stay low, airline and general aviation will face a shortage according to aviation industry executives (FAA, 1993).

\section{Aircraft Maintenance Technicians and Engineers}

In 1992, 10,636 aircraft maintenance technicians and engineers were hired; the number of new hires in 2005 is projected by the FAA to be 16,235 for the airlines and another 4,000 for general aviation, resulting in a $35 \%$ increase. If the FAA's projections are accurate, the need for maintenance technicians and/or engineers will grow twice as fast as the average for all occupations ( 2.5 vs. $1.3 \%$ annually). Approximately 220 schools in the U.S. operate under FAR Part 147 certificates producing an estimated 20,000 technicians with entry-level Airframe and Powerplant certificates (FAA, 1993). Of the 220 schools, 67 offer associate and baccalaureate degrees and gxaduate approximately 3,000 students annually (FAA, 1993). According to a recent FAA study there will be an inadequate supply of technicians and engineers since specialized training required to work on newer aircraft can only be received at a few schools (FAA, 1993). 


\section{Computer Scientists}

Computer systems analysts, computer engineers, and programmers held about 555,000 jobs in 1992. These individuals are employed in many different industries. Employment opportunities are expected to grow faster in all other occupations through the year 2005, and the supply of programmers is not expected to meet the demand (Gradler \& Schrammel, 1994). Important areas of growth will be in data communications, expert systems, the use of computer-aided software engineering tools, and the development and maintenance of data base management systems. Not unsurprisingly, given the growing use of computers, four of the 50 fastest growing positions in Money's survey are computer related (Marable, 1995).

\section{Engineers}

More than 25 major specialties in engineering are recognized by the professional societies, with numerous subdivisions in the major branches. In 1992, engineers held 1,354,000 jobs, with just under one-half of these jobs in the manufacturing industry (BLS, 1994a). Electrical engineers account for $26 \%$ of all engineers, mechanical engineers make up $17 \%$, and another $8 \%$ are aeronautical engineers. (BLS, 1994a).

Employment opportunities in engineering disciplines have been good for a number of years, and the trend is expected to continue through the year 2005 (BLS, 1994a). The computer, quantitative, and problem solving skills of engineers are in demand in almost any industry. Good job opportunities will continue because the number of jobs will grow while the number of degrees awarded in engineering is expected to remain near present levels through the year 2000 (BLS, 1994a; Gradler \& Schrammel, 1994). Engineering jobs will shift from defense-related work to other areas, primarily to the design and manufacturing of goods and services including the production of flight instruments and displays, radar instrument and microwave landing systems, and geosynchronous satellite communications. Through the year 2005, the demand for electrical and mechanical engineers is expected to equal the supply, while the number of aerospace engineers is expected to exceed the demand (ASME News, 1996; Gradler \& Schrammel, 1994).

\section{Meteorologists}

Meteorologists held about 6,100 jobs in 1992 (BLS, 1994a). The largest employer of civilian meteorologists is the National Oceanic and Atmospheric Administration which employs about 2,400 meteorologists; most of these individuals work for the National Weather Service (BLS, 1994a). Other meteorologists work for private weather consultants, research and testing services, and computer and data processing services. Employment of meteorologists is expected to grow as fast as the average for all occupations through the year 2005, due to expected increases in employment in the National Weather Service's field offices and increased use of private weather forecasting services (Gradler \& Schrammel, 1994). 
Table 3

Projected Employment Change for selected Aviation/Aerospace Related Occupations, 1992-2005 (thousands)

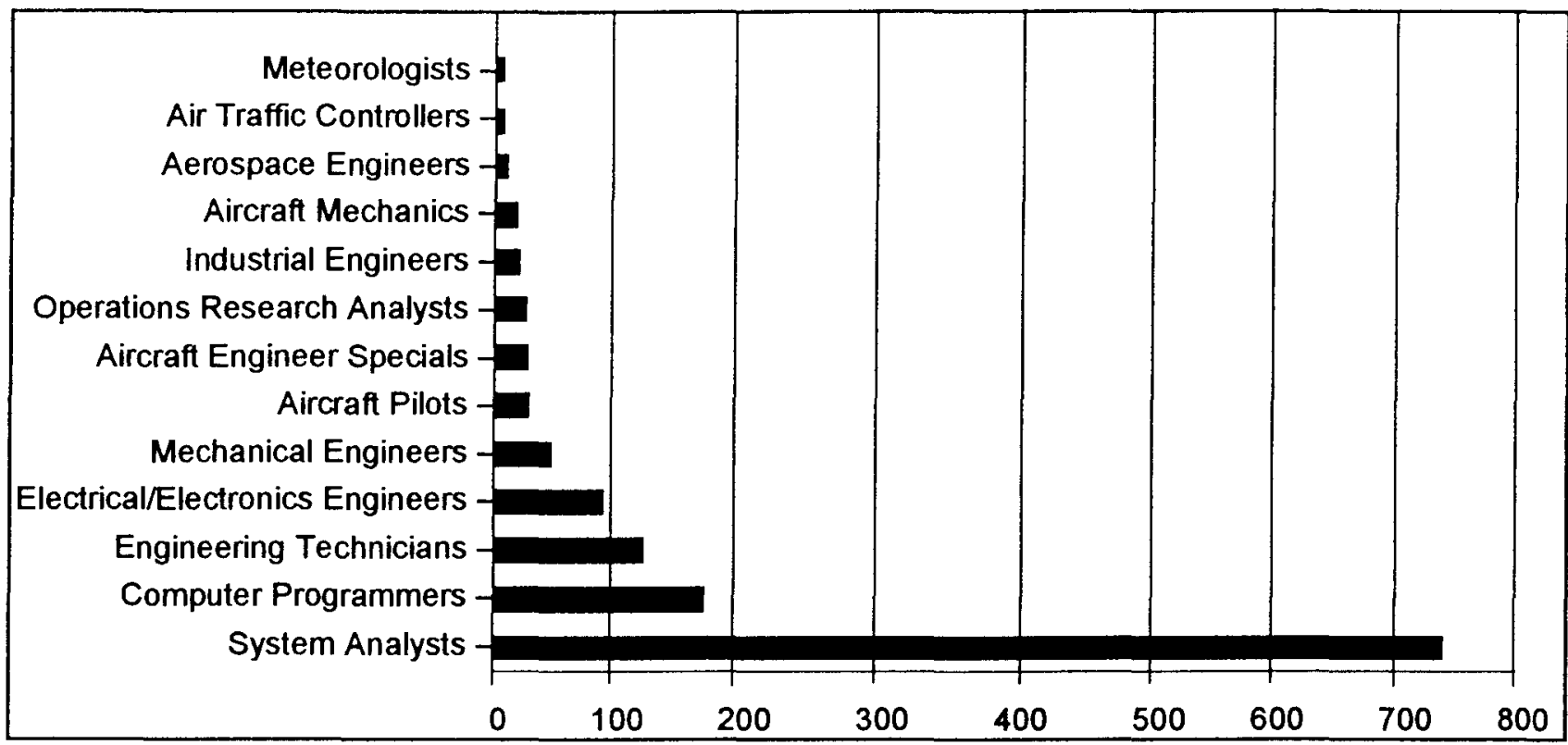

\section{Conclusion}

The prospects for the growth of the commercial airline industry, although not for the defense and government sectors, look very positive. The airline industry is restructing itself into a more efficient, highly competitive, and low-cost service industry. Every major airline has launched a program to cut costs. coupled with a growing economy and an increased number of airline passengers, the airlines are expected to show strong operating and net profits. As the number of passengers grow, the size of the world's commercial fleet growsalso. Correspondingly, the job prospects for those pursuing aviation and aerospace careers, providing they develop appropiate skills, looks better than it has in recent years.

\section{References}

Bureau of National Affairs (1995, March 6). DOT Officials Cite Improvements in Outlook for U.S. Airline Industry (Management Briefing). Washington, D.C.: Author.

Federal Aviation Administration (1993, August). Pilot and Aviation Maintenance Technicians for the Twenty-First Century: An Assessment of Availability and Quality. Pilot and Aviation Maintenance Technician Blue Ribbon Panel. Washington, D.C.:Author.

Field, D. (1995, January 8). The Washington Times, p. All.

Forecast for Mechanical Engineers in U.S.: 90,000 New Jobs by 2005. (1996, March). ASME News, 15 $(10), 1,7$.

Gradler, G. C. \& Schrammel, K E. (1994). The 1992-2005 Job Outlook in Brief. Ocaupational Outlook Quarterly 38(2), 2-36.

Hinson, D. R. (1995a, May 16). Remarks. Presented at the Regional Airline Association Annual Meeting, San Antonio, Texas. Available: http://www.faa.gov/apa/speeches/aoa/FRAA.htm 
Hinson, D.R. (1995b, June 27). Remarks. Presented at the National Airspace System Architecture Meeting, Washington, D.C. Available: http:/www.faa.gov/apa/speeches/aoa/FBNAS l.htm

Hinson, D. R. (1996a, January, 31). Remarks. Presents at Lehman Brothers Transportation Conference, Palm Beach, Florida. Available: http://www.faa.gov/apa/speeches/aoa/ehpr.htm

Hinson, D. R. (1996b, January 23). Remarks. Presented at a conference on U.S. Aviation in the 21 st Century, Washington, D.C. Available: http://www.faa.gov/apa/speeches/aoa/fo $123 . h t m$

Hinson, D.R. (1996c, February 21). Remarks. Presented at the Helicopter Association International HELI-EXPO '96 Rotorcraft Roundtable, Dallas, Texas. Available: http://www.faa.gov/apa/speeches/aoa/helo.htm

Hinson, D. R. (1996d, March 5). Remarks. FAA Annual Forecast Conference, Washington, D.C. Available: http://faa.gov/apa/speeches/aoa/forecast.htm

Kandebo, S.W. (1995). Re-emerging Market May Spur Engine Sales. Aviation Week and Space Technology, $142(11), 90-92$.

Ladesic, J. \& Hazen, D. (1995). A Course Correction for Engineering Education. Aerospace America 33(5), $22-27$.

Lopez, V. L. (1994). The U.S. Aerospace Industry-Doing Business Internationally. Aerospace America, 32 (7), 10-11, 43.

Marable, L. M. (1995). The Fifty Hottest Jobs in America. Money, 24 (3), 114-117.

Maul, G. P. (1994). Reforming Engineering Education. Industrial Engineering, 26 (10), 53-55, 67.

Meecham, M. (1994). Pacific Travel Grows in Atlantic's Shadow. Aviation Week and Space Technology, 141 (20), 31 .

Oberman, D. \& Nagle, R. (1995). The Job Market for the Class of '95. Planning Job Choices: 1995, pp. 17-22. Bethlehem, PA: College Placement Council, Inc.

Oklahoma State Regents for Higher Education. (1994, January). System-Wide Aviation/Aerospace Education Program Review. Aviation/Aerospace Task Force's Report to the Oklahoma State Regents for Higher Education. Oklahoma City: Author

Saunders, N.C. (1995). Defense-Related Employment Ret renches. Occupational Outlook Quarterly, 39 (2), $32-33$.

Shelley, K. J. (1994). More Job Openings-Even More New Entrants: The Outlook for College Graduates, 1992-2005. Occupational Outlook Quarterly 38 (11), 5-9.

Shifrin, C. (1995). Europe to Represent Major Segment of World Aircraft Market. Aviation Week and Space Technology 142 (11), 69-71.

Sparaco, P. (1994). LATA Forecasts Continues U.S. Market Growth. Aviation Week and Space Technology, $141(17), 30-31$.

United States Department of Labor, Bureau of Labor Statistics (1994a). Professional Specialty Occupations. Occupational Outlook Handbook, 1994-95. Chicago: VGM Career Horizons. pp. 75-238.

United States Department of Labor Bureau of Labor Statistics (1994b). Tomorrow's Jobs. Occupational Outlook Handbook, 1994-95. Chicago: VGM Career Horizons. pp.11-16.

Vadas, D. (1995). U.S. Aerospace Industry's Troubles Continue. Aerospace America, 33 (1), 14-16.

Velocci, A.L. (1995, March 13). U.S. Airline Profitability May Be Short-Lived. Aviation Week and Space Technology, 142 (11), 45-46.

Wilhilmsen, G. R. Forecast '95. Plane and Pilot, 31 (5), 50-53. 